\title{
Saliendo de la noche oscura. Experiencia religiosa de los refugiados guatemaltecos
}

\author{
RICARDO FALLA, S.J. \\ Centro de Investigación y Acción Social, \\ Centroamérica.
}

Sali sin ser notada ¿estando ya mi casa sosegada?

\begin{abstract}
¿Cuál es la importancia de conocer y sentir la experiencia religiosa de los relugiados, mayoritariamente indigenas, de Guatemala? La importancia proviene de que son "luz de las naciones" (Is. 49,6) como el pueblo de Israel cuando se encontraba triturado, herido como leproso, desaparecido, en exilio y desfigurado por los sufrimientos. Creemos que el pueblo indigena de Guatemala y en particular los refugiados en México es esa luz en estos momentos de la historia de la humanidad. Su experiencia ilumina, humaniza y evangeliza, como no humanizan e iluminan pueblos que son muy avanzados por su técnica, por su orden y disciplina, por su aparente ausencia de rupturas sociales, por la puntualidad de sus isenes y la abundancia de sus riquezas. "Las naciones" no necesitan a esos pueblos para mirar la luz, sino a los que paradójicamente carecen de apariencia de belleza, se encuentran en callejones sin salida, están sometidos a grandes pruebas de identidad y aun su existencia está ferozmente amenazada. Esos pueblos, como el de los refugiados, despiden rayos de luz invisible que penetra las conciencias y desde su debilidad las juzga.
\end{abstract}

Para entrar, pues, en el mundo interno de este pueblo vamos a hacer una aproximación de su experiencia en base a un par de testimonios que representan dos etapas de la historia reciente de dicha gente, la elapa inmediatamente posterior a la represión, cuando el concepto y la identidad de refugiados eran aún nacientes entre ellos, y la de un par de años después, cuando ya ha habido tiempo para reflexionar la experiencia y sistematizarla. Para ambas etapas escogeremos dos testimonios, el primero de un sobreviviente de la masacre de San Francisco, Nentón, ocurrida a 17 de julio de 1982, y el segundo de un catequista católico que desde un campamento escribe una carta a sus familiares distantes en abril de 1985 . Quizás ninguno de los dos sea una persona ordinaria, el primero porque pocos han sido los sobrevivientes y testigos oculares de cada paso de una masacre tan atroz donde murieron más de 300 personas a manos del ejército en una tarde; y el segundo, porque pocos habrán elaborado en cristiano su experiencia con tanta profundidad. Sin embargo, la calidad facilita el análisis de la estructura de su experiencia, como para poder suponer 
que esa misma estructura, con sus variantes más circunstanciales, se encuentra en la generalidad del pueblo, aunque no haya muchas personas privilegiadas, como éstas, que puedan explicitarla. No se trata pues de un análisis estadistico, ni las afirmaciones que haremos en este artículo pueden cruzar el umbral de lo hipotético.

El testimonio completo del sobreviviente de San Francisco ha sido publicado en Masacre de la finca San Francisco, Huehuerenango, Guaremala (Copenhague: IWGIA, 1983). Se encuentra traduciclo al inglés en Voices of the survivors (Cambridgc: Cullural Survival and Anthropology Resource Center, 1983). Sólo el análisis de la masacre se encuentra publicado en Estudios Centroamericanos (ECA), 1983, 4/7-418 (San Salvador: Universidad Centroamericana José Simeón Cañas). La carta del catequista ha sido publicada integra en Chrisłus.

\section{Experiencia del sobreviviente de la masacre}

\section{Noche oscura}

Una de las notas más sobresalientes de la experiencia de los sobrevivientes de las masacres y en general de la represión es el sentimiento de destitución, desnudez, impotencia, hambre y lalta de sentido, que aquí llamamos genéricamente noche oscura. Es desnudez porque muchos tuvieron que huir, como el testigo ocular de esta masacre, sin sombrero, sin otra muda, sin casi nada puesto. Es de impotencia, porque fueron dejados "con los brazos cruzados," sin trabajo, ni tierras, ni manera de ganarse la vida. Es de hambre, porque muchos debieron huir sin comida e incluso algunos niños pequeños se murieron en la huida. Es de oscuridad y de una pérdida temporal hasta de la capacidad de sentir, porque la masacre contemplada fue tan terrible que el que la pudo ver llegó a perder en esas horas la tristeza y el asombro para converlirse casi en un borracho que al caminar hacia México en busca de refugio no se daba cuenta si era ya de día cuando llegó: "a las 11 de la mañana será vine yo aqui (a México). ¡Pero como bolo (vengo)! Ya no me miro que está claro. Y no vengo ni triste. No pienso nada." Se trataba pues de una experiencia puntual de noche oscura que se extendería en el tiempo.

\section{Perdón a través del castigo injusto}

Otro rasgo de la experiencia es la percepción de la muerte de los masacrados como un castigo injusto inflingido a través de los hombres y a la vez como un perdón de Dios de los pecados de los masacrados, los cuales, aunque no merecían ese castigo, puesto que eran inocentes de la culpa que el ejércilo les atribuia, eran, sin embargo, como mujeres y hombres, pecadores. Los sobrevivientes de la represión afirman con una claridad meridiana que el ejército mató a inocentes y lo comprueban enumerando los niños, mujeres y ancianos que no podian ser insurgentes armados. Sin embargo, en su modestia y humildad de gente pobre afirman que no pueden llegar al cementerio perdonados a no ser que Dios borre sus culpas y recoja sus almas. ¿Como borra Dios sus culpas? 
No las quita desde fuera, sino que la misma muerte de los masacrados es la que los borra y por eso Dios los perdona. Asi. el sobreviviente de San Francisco exhortó a unos companeros que estaban a punto de ser ametrallados a tener ánimo porque la muerte injusta les daría esa reconciliación: "(les dije): no más, muchá, ahora sufrido de castigo allá nos vamos al cementerio perdonados."

\section{Compañeros, ¿suéltenme!}

Los inuertos se lueron perdonados, ¿pero el sobreviviente? Maravillosamente éste se libró del estallido de las granadas porque se tiró a tierra y los soldados más tarde lo confundieron con los cadáveres. Esta es, entonces, otra nota de la experiencia del sobreviviente, la conciencia de que ha sido liberado por Dios de la muerte. En los testimonios la atribución a la fuerza de Dios de esta liberación aparece con lrases sencillas. como "gracias a Dios," "primero Dios." "Dios es más grande," "“ay Dıos!," que tal ve 2 alguien que analizara la expresión humana reduciria a meras interjecciones con "dios" en minúsculas. Dios le inspiró al sobreviviente la ocurrencia que le salvó la vida y le dio fuerza para arriesgarse a practicarla, según él.

Pero también intervienen en esta liberación los difuntos recién masacrados. Ellos intervienen porque cubren con su sangre al testigo de modo que el ejército lo confunde como muerto. También intervienen, porque poco después el sobreviviente, antes de intentar zafarse del montón de cadáveres y huir con el riesgo de ser ametrallado por las postas nocturnas, ora a sus hermanos para que lo dejen en libertad.

¿Cuál es la libertad a la que él pretende llegar? ¿La libertad de los vivos o la libertad de los mucrtos? Como toda esta experiencia está preñada de dialéctica, también la experiencia de libertad encierra una gran paradoja. El arguye con los difuntos y les pide que lo suelten, que no lo mantengan amarrado a ellos con la solidaridad de la sangre y que lo dejen libre, porque ellos ya gozan de libertad. La paradoja es entonces que la libertad de los muertos se percibe como auténtico descanso y como una victoria contra el cerco del ejército, pero que ésa no es la libertad quc el sobreviviente ansía. El pide la de los vivos, él pide escaparse del juzgado cuslodiado por soldados, él pide salir al campo y respirar el aire de los árboles. Les reza asi a los muertos presentes: "compañeros, compañeros, sóltame me fue al campo! j(Ojalá) tengo yo suerte! Ah, ustedes ya están en libertad. ¡Suéltame! Yo me voy al campo, (les dije)."

\section{Soldados cabrones}

¿Pero de quién se liberó el sobreviviente? Aqui mencionamos otra nota que es la experiencia del mal, del engaño, del contrasentido, de la locura, del desorden y de la animalidad desenfrenada encarnados en el ejército. El sobreviviente se liberó de este ejército asesino. Los militares fueron percibidos como locos, porque mataron a inocentes, cuya inocencia era palmaria: niños, mujeres y ancianos; su locura se mostró desde que sc hicieron presentes en la aldea 
en los rostros contorsionados. El ejército fue percibido como engañoso porque reunió a la gente como si se tratara de una junta para beneficio del pueblo. Se le vieron procederes terriblemente contrastantes y desconcertantes, porque sacó a los niños menores de un año "con paz y caridad," casi arrullándolos, y luego les clavó la bayoneta en el estómago. El ejército desordena el mundo. porque no respeta ni a las autoridades militares locales nombradas por él mismo (comisionados), porque mala sin juicio previo a los hombres clentro del juzgado y asesina dentro de la iglesia a las mujeres sin respeto a Dios. El ejército tiene una mente caótica porque confunde a los hombres con los animales y a los animales con los hombres: en la mitad de la masacre descansan los soldados para comer un toro recièn destazado y en la mitad de la masacre un militar le abre el pecho a un campesino ya muerto, le saca ei corazón y se lo lleva a la boca.

Sin embargo, el testigo afirma que los soldados no son ni animales, ni demonios extraterrestres, ni la personificación del mal, porque ellos son hijos de Dios. Esto es lo que más lo confunde, que siendo hombres como los masacrados, hayan podido llegar a esos extremos que no son propios de humanos, sino de "cabrones," "cuerudos" y "animales." Olvidándose de que "son hijos de Dios como nosotros," se olvidan que ellos también comparecerán ante la justicia de Dios.

\section{Oración de liberación}

La experiencia de la fuerza del malvado despierta en los que están a punto de ser masacrados la necesidad de la oración para salir de esa situación extrema. La actitud orante es otra característica de esta experiencia. ¿De qué oración se trata? Se trata de una oración que se orienta fundamentalmente a pedir la liberación del ejército en ese momento. Es una oración intensa, "por todo mi corazón:" una oración repetida muchas veces. Pero no es una petición mágica, porque también se orienta a ofrecer a Dios la entrega de las personas que aguardan la muerte, si es que ya no hay otro remedio. Es una oración individual del sobreviviente, pero también es una oración colectiva, dirigida por algunos catequistas cuando están encerrados en el juzgado esperando el turno para ser acribillados fuera. También es una oración acompañada por el llanto de los niños, los cuales, aunque no articulen palabras con sentido, sirven de fondo desde donde están encerrados a la petición rítmica y casi desesperada de los hombres. Es una oración que se dirige a Dios directamente y' a los masacrados presentes, considerados como vivos. Por eso dice el testigo: "me estoy rezando a aquellos - los muertos - a hablarles espiritualmente." Por fin, es una oración que conduce a una acción con riesgo, porque después de terminada se levanta, se quita las bolas de hule para no hacer ruido, salta por la ventana del juzgado y, como una culebra, se arrastra lentamente para no ser detectado por los soldados que hacen la vigilancia. Pudo haber sido ametrallado como orros que habian intentado huir horas antes, pero él se arriesgó y fue salvado por Dios y los difuntos. 


\section{Rasgos de Dios}

De lo dicho hasta aquí se destacan ya algunos rasgos de la imagen de Dios del sobreviviente. Dios es principalmente el que libera, tanto a los difuntos que salen de las amarras de la vida y del dolor a la libertad, como a el mismo que recibe la fuerza y la inspiración de El. Dios es como el campo de esa noche de julio donde los masacrados ya vivos pueden respirar y burlar al ejército que creyó haberlos dominado. Dios, entonces, no sólo es el liberador, sino la liberlad misma.

Dios es liberador porque es el más fuerte, el más grande, el definitivamente justo y el que dice la última palabra. Domina al ejército, porque libera a los hombres de su muerte. Juzga por último, porque también los oficiales se presentarán ante su tribunal. Es el más duradero, porque los soldados morirán, mientras El vive siempre.

Es el más grande y el más fuerte, porque es el Padre creador de todos los hombres, también de los soldados, aunque estos reprimen a los pobres y no se comporten como sus hijos. Y es el Padre perdonador que ante la sangre de los masacrados olvida todas las ofensas de los hombres, reconciliándolos entre si y haciendo posible la solidaridad que de la vida. Sin embargo, en las expresiones de la experiencia no se menciona cómo se da esta reconciliación con los responsables de las masacres. Más bien se insinúa que en el juicio delinitivo ellos serán castigados por la justicia del que también es castigador.

\section{Nos nacen hermanos}

Por hacer referencia a Dios, esta experiencia es religiosa, pero a la vez es una experiencia de solidaridad y hermandad. ¿Cómo lo puede ser si el factor del mal, del engaño, la ruptura y la muerte están tan presentes? Precisamente por eso mismo. Primero, nace una solidaridad especial con los muertos. Ellos son hermanos, porque de tal manera han asemejado y manchado con su sangre al sobreviviente que lo han salvado del ejército. Entonces su cercania se vuelve profunda y para siempre, porque el dolor de su pérdida llega hasta el corazón y las lágrimas internas nunca desaparecerán: "bajo la pena que estoy mi corazón, por los muertos, porque yo estoy mirando cómo mueren mis hermanos, lodos, compañeros, compadres, lodos, como somos hermanos entre todos. Como por eso estoy llorando mi corazón toda la vida."

Segundo, nace también una nueva solidaridad y fraternidad con los campesinos mexicanos. La primera era una fraternidad con los muertos. Esta es con los vivos. Se percibe que ellos of recieron por la gracia de Dios hospedaje a los que huían del ejército y que si no hubiera sido por ellos y por México, hubieran muerto a manos del ejército de Guatemala. Su hermandad se tiñó de compasión. Cuando llegó el sobreviviente al ejido más cercano, los campesinos mejicanos lo vieron con las ropas manchadas de sangre, como si hubiera desatado una res, y le dijeron: "hay posada, que descanse el pobrecito." Por eso, los mexicanos son hermanos y verdaderos hijos de Dios. Incluso, al mis- 
mo gobierno de México se le atribuye esta cualidad: "gracias a Dios por nuestros hermanos aquí en México el gobierno nos ha dado un poco hospedaje, por la gracia de Dios. Tal vez es un hombre hijo de Dios."

Dentro de estos nuevos hermanos está la iglesia de San Cristóbal y su obispo don Samuel Ruiz ante quien narraron los sobrevivientes su trágico y conmovedor relato. A mi, como sacerdote llevado por agentes de pastoral de la diócesis a esos campamentos de relugiados, tambièn me narraron la terrible historia. Luego confeccionaron la lista de los masacrados para que sus nombres fueran leidos en la misa. Cuando daban información, con mucho respeto repetían la palabra "padre, padre," al cabo de cada frase. Pero cuando nosotros hicimos preguntas que se salian de lo correspondiente, no por ser sacerdote me confiaron el lado delicado de su vida en la comunidad de Guatemala que decia relación con las actividades guerrilleras. La nueva solidaridad que se les abria y el respeto hacia la Iglesia y sus representantes no suponia necesariamente una confianza imprudente que hiciera precisión del conocimiento de las personas y de su lealtad.

\section{Sentimientos que destacan}

Dentro de todas estas vetas de la experiencia religiosa del sobreviviente hay una par de constelaciones de sentimientos que destacan, la primera de cara al pasado y la segunda de cara al futuro. La primera gira alrededor de la tortura de la pregunta sin respuesta muchas veces repetida, por qué, por qué a los inocentes, especialmente a los niños, mujeres y ancianos, se les asesinó de esa manera. Esta pregunta puede también invertirse: ¿por qué hombres e hijos de Dios, como son los soldados, actuaron como animales? Se trata de la pregunta acerca del mal en el mundo. La ausencia de respuesta satisfactoria quiebra los esquemas racionales del pensamiento y es una noche oscura de la inteligencia que por el lado efectivo es correspondida con la destitución por la pérdida de los seres más queridos. Esta soledad y esta noche de sentido hacen que el hombre llore en su corazón con una pena interminablc y que cobije una cólera contra el gobierno que cruzará generaciones. Esta soledad oscura es una experiencia de Dios por ausencia y sobre ella, como sobre un horizonte negro, relucen mejor y con más purcza las luces de fe en El, como el agradccinicnto por la liberación de la muerte.

Mirando al futuro la constelación tienc como centro una incertidumbre que el refugiado llama "pena" respecto a la comida, al vestido, al dinero, al trabajo. La querida tierra con la milpa y los cafetales quedó atrás. La casa fue quemada. Es imposible volver. México es el terreno de la libertad, porque alli no domina el ejército que masacra, aunque a veces haga incursiones, pero a la vez la situación misma de destitución es una impotencia parccida a una cárcel: "en eso estamos pena nosotros también con nuestras familias. Si, ahorita estamos refugiados, estamos libres. Pero la comida, los gastos... Digamos que estamos en calaboza ya por causa de ellos (los soldados)." Entre las dos constelaciones de sentimientos hay un acento sobre la que mira al pasado. 
Esta es la experiencia inicial del refugiado, quien apenas tiene identidad como lal. A estas alıuras - dos meses despucs de haber cruzado la rayatodavía no dice que es refugiado, sino que está re「ugiado. Habla más del aconlecimienıo terrible de la masacre, la está desentrañando en su recucrdo y lucha por encontrarle algún sentido; y habla menos del futuro que apenas se lo está abriendo para el cual no liene ningún proyecıo.

\section{Experiencia del refugiado}

La experiencia del sobreviviente se subsume dentro de la experiencia del refugiado que lleva ya varios años en México y ha tenido largos tiempos para reflexionar sobre su historia reciente y para adaplar su vida a nuevas dificultades. Estas van cambiando poco a poco el enfoque de su experiencia del pasado hacia cl futuro, sicndo la principal y decisiva, nos parece, la medida del gobierno mexicano de la reubicación de principios de 1984 .

\section{Identidad del refugiado}

Una primera nota de esta nueva experiencia es la identidad del refugiado como refugiado. Esta identidad nace de una historia común frente a Guatemala, pero especialmente frente a México, donde los refugiados son contrastados como extranjeros. Esta identidad se extiende por toda la frontera del norte a sur y tiene como sustentación identidades previas, como el parentesco, la procedencia de un mismo municipio, la lengua, la etnia indigena y la misma nacionalidad, pero no se agota con ellas. Asi, por ejemplo, un ixtahuacaneco de habla mam se identifica no sólo como ixtahuacaneco con los grupos procedentes de San Ildefonso Ixtahuacán dispersos a lo largo de la frontera, sino como refugiado.

La historia común vivida recientemente es una cadena de sufrimientos: "¿Qué triste es la vida de nosotros los refugiados, los pobres campesinos, cuánto hemos estado sufriendo! ¡Muchísimos!... Hemos sufrido de hambres y un largo caminatos, en el lodo, hemos dormido sin cama, con frio, bajo la lluvia, el agua corre bajo nuestra espalda. Los ejércitos tras dia tras dia va pegando detrás de nosotros, hasta que salimos a refugiar en el territorio de México." Cualquier refugiado que oiga esta lista de padecimientos se reconoce en ellos, los haya vivido exactamente como están descritos, o los haya visto vividos en otros. Son un tesoro común de experiencias.

Después de esta cadena de persecuciones se da un paréntesis de relativa tranquilidad en sus vidas que dura como año y medio en México. Pero luego se reanudan las penas cuando se da el decreto de reubicación por parte de México. Así continúa el catequista el resumen de su vida reciente: "...pues bien, hermanos, al estar gozando unos dias por parte de México, desgraciadamente se vino la exigencia de las autoridades y nos han sacado muy esforzosamente para Campeche."

La identidad que nace de esta historia expresa y hace una nueva hermana- 
dad, como no se veía aún en la experiencia del sobrevivienie. Esta es la de los refugiados entre sí. Por eso, el catequista que envia la carta que estamos citando la encabeza como si fuera San Pablo a los corintios o a los galatas: "a los hermanos refugiados." Para él, los refugiados de lejos son sus hermanos, no sólo por haber entre ellos parientes y gente del mismo municipio, sino porque son refugiados.

\section{Cristo en el centro de lodo}

Otra nota, la más importante y central de la titueva expericncia, es la explicitación que coloca a Cristo Jesús en la milad de $10 d a$ la vida. Esta explicitación significa un avance respecto a la experiencia del sobreviviente. Su punto de arranque es la semejanza cnlre la vida de Cisto $y$ la del refugiado: "Cristo cuando tuvo en la tierra, ha sido refugiado en otra pais, fue perseguidos por los grandes, fue rechazados, peregrino, fue forasicros por causa del bien... Igual manera que nosotros somos un relugiados, somos peregrinos, forasteros, estamos perseguidos, rechazados por los hombres, somos despojados y plastados por los grandes." Sin duda que para la reflexión sobre esta semejanza ayudó la lglesia y sus agentes de pastoral, tanto los que formaron a estos catequistas en Guatemala, como los que visitan los campamentos desde la diócesis de San Cristóbal, pero lo lundamental es que la scmejanza entre la vida de Cristo y la del refugiado es real, objetiva y evidente. Fácilmente es entonces reconocida. Es como si dicha semejanza no existiera, haria falta torcer y alambicar el evangelio para encontrarla.

El reconocimiento de esta semejanza no es un simple acto de reflexión intelectual, sino que es un reconocimiento de fe que abre las puertas a un lorrente de fuerzas internas. Queremos decir que no sólo se da una constatación de esa semejanza, sino que se cree que ella es participación de la fuerza de Cristo Jesús que se manifiesta en la resurrección. Por eso, en esta nueva experiencia se acentúa la resurrección, como no se hacía en la experiencia del sobreviviente, aunque este reconociera su vida como liberación de Dios. De esta manera es como el refugiado puede convertir su tristeza en gozo: "hasta el fondo de mi corazón siento una tristeza, da gana de ilorar, con mis lágrimas, pero al ınismo tiempo vuelvo alegre con Cristo Jesús." Sus lágrimas, entonces, no son un mero desahogo, sino la gracia del consuelo de Cristo resucilado quien se le aparece por dentro. Esto no es masoquismo que se goza del sufrimiento, porque el masoquismo paraliza, subyuga, debilita y destroza, y esta experiencia motiva, libera, fortalece y construye al hombre y al pueblo interiornente, ya que, como dijimos, este consuelo y esta alegria procedente de la fe de estar participando en la vida de Jesucristo resucitado: "sepan ustedes pues que este día (;ahora!) ya estamos en la vida de nuestro Señor Jesucristo."

Como esta alegría motiva, de ella nace una fortaleza para seguir luchando en el futuro: "tengan valor por estar resistiendo en estos tiempo, será dias de angustias." Después de año y medio de descanso en los campamentos, el futuro se enturbió con los ataques del ejército guatemalteco y la medida de reubicación, pero entonces también se abrió un nuevo reto que hizo cambiar las pers- 
pectivas para no sólo ver hacia atrás. sino extraer de la experiencia de la masacre y represión nuevas fuerzas. El relo del fuluro le exige entonces valor, paciencia y claridad. Valor, porque los enenigos son muy poderosos y se alian entre ellos. Paciencia, porque los "dias de angustia" se prolongarán y no se conoce cuál será su fin, ni cuándo. Y claridad, porque las tentaciones del enemigo no sólo llegan con la fuerza bruta, sino que se revisten de argumentos su. liles, de promesas que confunclen e incluso de razones religiosas manejaclas por grupos evangélicos y católicos conformistas: "hermanos, pues ojalá que no conlundinos en este liempo. El evangelio de Cristo se cumple en nosolros. Pidamos a Dios ntestio valor pard que tengamos palciencia."

\section{F. malo lienta}

La presencia del malo es otra de las notas de esta experiencia y en este senlido continúa la experiencia del sobreviviente de la masacre. Pero las intenciones del malvado -el gobicrno de Ciuatemala - han cambiado. Ya no se trata de acabar con las aldeas "subversivas," sino de que los refugiaclos regresen al pais de origen para someterlos allí a la dominación de los lombres poderosos. Dentro de este plan el refugiado ve que se ubica la política de reubicación del gobierno de México. La reubicación es sólo un paso para luego, estando el refugiado a 300 kilómetros de Guatemala, confundirlo y lograr su repatriación voluntaria: "(las autoridades mexicanas) nos han sacado muy esforzosamente para Campeche, metieron la gran miedo a los hermanos y asi desmoralizaron lodos los hermanos hasta que convencieron ir en Campeche. El gobierno guatemalteco se alegra bastante para lograr la conversión de nosotros, los refugiados, al llegar en Campeche y quedar dominado por la politica de los hombres poderosos para regresar en Guatemala con ellos, para sernos hijos del demonio y no para ser santos."

Enionces, cuando el catequista de la carta exhorta a sus hermanos a resistir, probablemente se refiere a la resistencia a la reubicación (aunque no lo expresa claro) y seguramente apunta a una resistencia ideológica para no ser convencidos ("conversión") en Campeche a regresar como esclavos engañados a Gualemala. La reubicación de Chiapas a Campeche se ve así como una tentación religiosa para perder la santidad propia de los hijos de Dios, los cuales son libres.

Queremos recalcar aquí la profundidad de la visión del refugiado de los planes contrainsurgentes del gobierno de Guatemala, porque ordinariamente se ofrecen razones más superficiales, aunque válidas, para explicar la resistencia a la reubicación, como el miedo al cambio de clima, la amistad con los campesinos mexicanos y aun el temor de perder la identidad como guatemaltecos. Aqui aparece, dentro del horizonte de la fe en Jesucristo, una razón más de fondo: que en Campeche, lejos de la frontera, más fácilmente podrán ser confundidos para aceptar la repatriación voluntaria, la cual puede llevar a la muerte a algunos y a la sujeción a todos los que sobrevivan.

Así es como en el refugiado cambia la apreciación acerca de las autoridades mexicanas. El sobreviviente de la masacre daba gracias a Dios porque el 
gobierno de México era hijo de Dios, pero el refugiado ya no sostiene este juicio, porque la reubicación iniciada en 1984 se llevó a cabo a la fuerza ("esforzosamente"), con amenazas ("metieron la gran miedo") y con presión ("desmoralizaron lodos los hombres"). Sin embargo, no equipara el refugiado al gobierno de México con el de Guatemala, sobre el cual profeliza grandes cástigos, porque el gobierno guatemalteco y su ejército masacran y cl de México no ha cometido esas barbaridacies, $y$ porque el guatemalieco es la causa últuna de la reubicación y el mexicano el cjecutor de ella. Por eso, según esta visión, la reubicación no es un acto de soberania de México, sino una acción de sujeción a la presión guatcmaltcea.

Por eso, sobre el ejército de Guatemala y su gobierno llegará el clía del castigo, como también muy de paso lo afirmaba el sobrevivicnte de la masacre. Dice el catequista: "cuántos los hermanos han sido secuestrados, torturados. escupiados, han cortado sus orejas, han sacados sus ojos, han cortado sus brazas y sus pierna como una gallina." ['or esos crimenes, los responsables recibirán su castigo, no sólo cuando lleguen al juicio de Dios, como lo ponia el sobreviviente, sino en esta misma vida: "recargarán y caigarán sobre (ellos) todo la sangre de los inocentes que hall derramado en la tierra." Pero no sólo por las masacres recibirán esa pena, sino por la hipocresía y por el intento de engañar a los refugiados para convertirlos en hijos del demonio. Este castigo también caerá sobre los que se prestan como instrumentos religiosos a esta confusión: "pobres de ustedes los maestro de la ley, pariseo, hipócritas, cierran a los hombres el reino de los cielos, no entran ustedes, ni dejen entrada a los que quieren entrar, hipócritas, ustedes corren mar y tierra para lograr la conversión de un pagana y cuando se ha convertido to hacen hijo del demonio."

Por eso, como dijimos arriba, el catequista refugiado pide para sus hermanos mucha claridacl fundamentándose en la escritura: "hermanos pues ojalá que estemos bien clara lo que dice la biblia, para nosolros los pobres en el reino de los cielos." Si exhorta a valorar la pobreza es para desechar las ofertas de mejoria que se les hacen para comprarlos y luego someterlos.

\section{¿Quién es santo?}

Como ya ha ido apareciendo, otra nota de la experiencia del refugiado es la santidad. ¿Cómo se experimenta la santidad? ¿Se experimenta como sacralidad que lo separa del mundo y lo encierra en las ermicas para alabar a Dios y no contaminarse de la suciedad de la práctica? No. Porque para el refugiado la santidad consiste en la participación de la vida de Jesucristo: "querem.os ser santos y consagrados en Cristo Jesús." Por eso, la grandeza y trascendencia de Dios, que se llama santidad, será experimentada en la práctica de la vida de semejanza con Jesucristo, cuya más clara expresión es la persecución. Alli es donde a la vez se dará la adoración y el verdadero culto, aunque esto no supone, como veremos inmediatamente, la exclusión de la oración.

Entonces, santidad significa pasar muchas persecuciones. Santidad significa ser traslúcido y limpio en la predicación del verdadero evangelio, no como 
algunos creyentes que para no ser perseguidos tapan parte de las escrituras. Santidad significa romper las amarras de la injusticia y no sólo doblar la cabeza ante Dios y levantar las manos al cielo. Santidad, en fin, significa ser una ofrenda agradable al señor Yahvé, como su hijo lo fue, a través de los sufrimientos a los que lleva la predicación limpia y la práctica de la justicia. A continuación copiamos el párrafo entero de la carta yue analizamos:

Por eso hermanos, los que queremos ser santos y consagrados en Cristo Jesús, pues tenemos que pasar por muclias pruebas y muy perseguidos, principalmente nosotros los católica estamos más perseguiclos, queremos predicar la verdadero evangclio de Cristo, no queremos lapar ninguna par. te de la escritura y así serernos más perseguidos.

Hermanos, pues, al aser creyente en Ciristo Jesuis, quiere mucho esiuclios. más práctica, vale la pena estamos perseguidos pero queremos se cumple el evangelio, queremos que hayga la justicia, no queremos yuc hayga la injusticia. Los creyentes no solamente doblar la cabeza al cielo, levantar las manos al frente, sino romper las cadenas de la injusticia, a los amarrados, a los oprimidos, este es el verdadero ayuno que. Dios Yave le gusta. Isajas $58,1-8$.

La experiencia de santidad en la persecución no excluye la oración, sino que la orienta precisamente a la resistencia, a "soportar en este tiempo." Sin la ayuda de Dios será imposible mantener esta resistencia, aunque no se experimente más que la ausencia de Dios. Pero de nuevo, dada la centralidad de Cristo en toda la vida, la oración a Dios Padre es a la vez participación en Cris10, puesto que El ruega por nosotros a su Padie. Esa oración, a la vez, es constructora de hermandad antes los refugiados, puesto que es mutua: "piden a Dios la ayuda, oren a Cristo para que él ruega por nosolros al Dios Padre, oren por nosotros y nosolros oremos por ustedes para soportar en este tiempo."

\section{Las masacres y la vida}

Aunque la experiencia del refugiado ya está orientada al fuluro y a la resistencia (ideológica), se mantiene presente otra nola que sobresalía más en la experiencia del sobreviviente, la cual es el asombro ante el contraste de los que murieron y de los que están vivos.

¿Qué sentido tiene la muerte de todos los inocentes que derramaron sı sangre en la querida tierra de Guatemala? ¿Ticne algún sentido? ¿Siguc torturado el refugiado por esta pregunta como el sobreviviente de la masacre? Parece que la oscuridad de la pregunta sin respuesta satisfactoria ya ha cedido en este momento (abril 1985) a la luz de la fe y aunque no se pueda hablar de un sentido racional de dichas muertes, el ánimo del refugiado ha encontrado en Jesucristo la mediación simbólica (o sacramental) para intuir en esas muertes absurdas una luz: "muchos los hermanos han dado su vida, han derramado su sangre por sus hermanos." La luz descubre en ese absurdo, pues eso son las muertes, una vida para los demás. 
No se trata en esta luz sólo de la experiencia de la sangre benéfica de los masacrados que camuflaron al sobreviviente del ejército y lo soltaron en libertad, sino la sangre benéfica de Jesucristo, quien le comunica la fuerza de fondo a todas las muertes. Jesucristo presente en la historia del refugiados resume en su vida a Indos los que huyen del ejército, caen abatidos bajo las balas de los Galiles y mojan la tierrá con su sangre y da por su resurrección una fuerza infinita a la sangre de todos ellos.

A esta inserción de los perseguidos y masacrados en Jesucrislo, particularmente de aquellos más palmariamente inocentes, como los niños tiernos, se le llama "bautismo de sangre." Los padres de estos niños se apenarian porque el sacerdote no los habria bautizado, ya que la costumbre del bautismo en esa cultura está muy engranada. A ellos va la palabra de confianza del catequista refugiado: "miles de inocentes han muertos, que no conoce el pecado todavía, pues ojalá que Dios los ha puesto en su mano las almas de esos hermanos. Muchos los hermanos han dado su vida, han derramado su sangre por sus hermanos. Pues han recibido un bautismo de sangre."

$Y$ los vivos que no cayeron bajo las balas enemigas, ifueron ellos liberados por Dios, como lo experimentó el sobreviviente? ¿El refugiado tiene la misma experiencia? Básicamente sí, aunque éste no acude en la elaboración de su pensamiento a instancias concretas para mostrarlo, sino que sólo habla de una voluntad de Dios constatada por el pueblo. Esta voluntad consiste en que "Dios no quicre que morimos todos." Evidentemente esta afirmación no se apoya sobre una lógica apodictica. Se basa en la experiencia de que los refugiados están vivos y en la intuición (fe) y confianza (esperanza) de que Dios no permitirá por su amor a los pobres el genocidio completo. Las masacres pueden diezmar al pueblo, pero no pueden acabarlo. Y no pueden acabarlo, porque si asi fuera Dios sería derrotado por el mal. Pero Dios es vencedor y la prueba de que lo es es que su hijo, que en sí resume a todos los pobres perseguidos, vive. Su hijo Jesucristo fue resucitado.

Ahora bien, esta victoria de Dios, que se maniliesta en el gozo de vivir, es una exigencia continua a seguir luchando: "pues demos gracias a Dios por estar gozando otros dias más. Dios no quiere que morimos todos, sino Dios quiere a los que estamos vivos todavía esforzamos la lucha para llegar a la meta en nuestro Señor Jesucristo, y estar bien clara por nuestra vida de hoy, esta temporada."

\section{Rasgos de Dios}

De todo lo dicho, ¿cómo podemos caracterizar la imagen de Dios de refugiado? Un contraste con la del sobreviviente de la masacre puede iluminar este punto, si tenemos en cuenta que no son dos imágenes exclusivas, ni contradictorias, aunque debido al momento que cada uno está viviendo en una se acentúen algunos aspectos y en la otra otros.

Podríamos decir que la del refugiado es la imagen de un Dios más hombre (Jesucristo) que Dios, de un Dios más hermano que padre, de un Dios más de 
resistencia que de liberación puntual maravillosa, más de esfuerzo que de gratitud, de un Dios más parcial que universal, más castigador de! malvado que perdonador del pecador inocente, más del futuro que del pasado, nás dialéctico (perseguido y resucitado) que univoco (el más grande). más de resurrección y de luz que de oscuridad $y$ de prueba de muerte.

Sobre este último punto, queremos indicar que aunque el refugiado mencione la cadena de sufrimientos de su pueblo, sin embargo, concinuamente invicrte su experiencia con la le en Jesucristo, sacando luz de la oscuridad, consuelo de la tristesa, go/o de la pacienciá, resistencia de la clebilidad. Su fe, por eso, es re de vida, aunque esté acosado por las penas y las anguslias.

No queremos decir que la te del sobreviviente lenga un Dios de muerte. Nada más contrario a la prolundidad de su experiencia religiosa del Dios que lo liberó. Pero si que, debido a la cercania de la masacre y a la oscuridad en que se debate por encontrar respuesta a su pregunta torturadora, su Dios es más el del misterio, de la noche oscura y de la muerte espiritual, que el del camino, de la luz y del consuelo íntimo.

\section{Fraternidad y resurrección}

Por lin, para enlazar con la experiencia del refugiado de su identidad como tal, queremos mostrar cómo la hermandad nueva de los refugiados entre si se comprende y siente como una gracia de la resurrección de Cristo. ¿Cómo se cntiende esto?

El refugiado escribe a sus familiares lejanos y les dice que esa comunicación es una resurrección. Ellos no sabian si él, su esposa e hijos estaban vivos. Ellos no sabian si los demás de la aldea habian caido bajo las balas del ejército. La comunicación de la carta lleva precisamente como una de las finalidades informar sobrc quiénes viven y quiènes ya no. Por eso el saludo del catequista es como la resurección del que estaba muerlo, pero he aqui que, oh sorpresa, vive. $Y$ esa resurrección es la misma de Jesucristo.

La commuicación de la noticia no es un hecho informalivo, seco y lirio, sino que a la vez es la transmisión de un mujo de emoción, de cariño, de lágrimas, de consuclo, propio de las visilas del resucitado a los suyos: "llegue a todos ustedes (esta carta) con todo aquel cariño de mi corazón, saludando por usiedes uno de sus hermanos o familiar suyos de nombre XX. que hoy he resucirado para poder saludarle con lodo ustedes, pucs saben ustedes desde cuando hemos despidido sin poder comunicar nada."

Mćxico, 5 de julio de 1985. 
No se trata en esta lız sólo de la experiencia de la sangre benéfica de los masacrados que camuflaron al sobreviviente del ejército y lo soltaron en libertad, sino la sangre benéfica de Jesucristo, quien le comunica la fuerza de fondo a todas las muertes. Jesucristo presente en la historia del refugiados resume en su vida a todos los que huyen del ejército, caen abatidos bajo las balas de los Galiles y mojan la rierra con su sangre y da por su resurrección una fuerza infinita a la sangre de todos ellos.

A esta inserción de los perseguidos y masacrados en Jesucristo, particularmente de aquellos más palmariamente inocentes, como los niños tiernos, se le llama "bautismo de sangre." Los padres de estos niños se apenarian porque el sacerdote no los habria bautizado, ya que la costumbre del bautismo en esa cultura está muy engranada. A ellos va la palabra de confianza del catequista refugiado: "miles de inocentes han muertos, que no conoce el pecado todavía, pues ojalá que Dios los ha puesio en su mano las almas de esos hermanos. Muchos los hermanos han dado su vida, han derramado su sangre por sus hermanos. Pues han recibido un bautismo de sangre."

$\mathrm{Y}$ los vivos que no cayeron bajo las balas enemigas, ifueron ellos liberados por Dios, como lo experimentó el sobreviviente? ¿El refugiado tiene la misma experiencia? Básicamente sí, aunque éste no acude en la elaboración de su pensamiento a instancias concrelas para mostrarlo, sino que sólo habla de una voluntad de Dios conslatada por el pueblo. Esta voluntad consiste en que "Dios no quierc que morimos todos." Evidentemente esta afirmación no se apoya sobre una lógica apodictica. Se basa en la experiencia de que los refugiados están vivos y en la intuición ( $f e$ ) y confianza (esperanza) de que Dios no permitirá por su amor a los pobres el genocidio completo. Las masacres pueden diezmar al pueblo, pero no pueden acabarlo. $Y$ no pueden acabarlo, porque si asi fuera Dios sería derrotado por el mal. Pero Dios es vencedor y la prueba de que lo es es que su hijo, que en si resume a todos los pobres perseguidos, vive. Su hijo Jesucristo fue resucitado.

Ahora bien, esta victoria de Dios, que se manifiesta en el gozo de vivir, es una exigencia continua a seguir luchando: "pues demos gracias a Dios por estar gozando otros dias mas. Dios no quiere que morimos todos, sino Dios quiere a los que estamos vivos todavía esforzamos la lucha para llegar a la meta en nuestro Señor Jesucristo, y estar bien clara por nuestra vida de hoy, esta temporada."

\section{Rasgos de Dios}

De todo lo dicho, ¿cómo podemos caracterizar la imagen de Dios de refugiado? Un contraste con la del sobreviviente de la masacre puede iluminar este punto, si tenemos en cuenta que no son dos imágenes exclusivas, ni contradictorias, aunque debido al inomento que cada uno está viviendo en una se acentúen algunos aspectos y en la otra otros.

Podriamos decir que la del refugiado es la imagen de un Dios más hombre (Jesucristo) que Dios, de un Dios más hermano que padre, de un Dios más de 
resistencia que de liberación puntual maravillosa, más de esfuerzo que de gratitud, de un Dios más parcial que universal, más castigador del malvado que perdonador del pecador inocente, más del futuro que del pasado, más dialéctico (perseguido y resucitado) que univoco (el más grande), más de resurrección y de luz que de oscuridad y de prueba de muerte.

Sobre este último punto, queremos indicar que aunque el refugiado mencione la cadena de sulirimientos de su pueblo, sin embargo, continuamente invierte su experiencia con la lé en Jesucristo, sacando lus de la oscuridad, consuelo de la Iristeza, gozo de la paciencia, resistencia de la clebilidad. Su le, por eso, es fe de vida, aunque esté acosado por las penas y las angustias.

No queremos decir que la le clel sobreviviente lenga un Dios de muerte. Nada más contrario a la profundidad de su experiencia religiosa del Dios que lo liberó. Pero sí que, debido a la cercanía de la masacre y a la oscuridad en que se debate por encontrar respuesta a su pregunta torturadora, su Dios es más el del misterio, de la noche oscura y de la muerte espiritual, que el del camino, de la luz y del consuelo intimo.

\section{Fraternidad y resurrección}

Por fin, para enlazar con la experiencia del refugiado de su identidad como tal, queremos mosirar como la hermandad nueva de los refugiados entre si se comprende y siente como una gracia de la resurrección de Cristo. ¿Cómo se entiende esto?

El refugiado escribe a sus lamiliares lejanos y les dice que esa comunicación es una resurrección. Ellos no sabian si él, su esposa e hijos estaban vivos. Ellos no sabian si los demás de la aldea habian caido bajo las balas del ejército. La comunicación de la carta lleva precisamente como una de las finalidades informar sobre quiénes viven y quiènes ya no. Por eso el saludo del calequista es como la resurección del que estaba muerto, pero he aqui quc, ol sorpresa, vive. $Y$ esa resurrección es la misma de Jesucrisıo.

La comunicación de la noticia no es un hecho informalivo, seco y frio, sino que a la vez es la ıransmisión de un flujo de emoción, de cariño, de lágriınas, de consuelo, propio de las visitas del resucitado a los suyos: "llegue a todos ustedes (esta carta) con todo aquel cariño de mi corazón. saludando por ustedes uno de sus hermanos o familiar suyos de nombre $X X$. que hov he resicilado para poder saludarle con todo ustedes, pues saben ustedes desde cuando hemos despidido sin poder comunicar nada."

México, 5 de julio de 1985. 
No se trata en esta luz sólo de la experiencia de la sangre benéfica de los masacrados que camullaron al sobreviviente del ejército y lo soltaron en libertad, sino la sangre benéfica de Jesucristo, quien le comunica la fuerza de fondo a todas las muertes. Jesucristo presente en la historia del refugiados resume en su vida a todos los que huyen del ejército, caen abatidos bajo las balas de los Galiles y mojan la tierra con su sangre y da por su resurrección una fuerza infinita a la sangre de lodos ellos.

A esta insercion de los perseguidos y masacrados en Jesucristo, particularmente de aquellos mas palmariamente inocentes, como los niños tiernos, se le Ilana "bautismo de sangle." Los padres de estos niños se apenarian porque el sacerdote no los habria bautizado, ya que la costumbre del bautismo en esa culıura está muy engranada. A ellos va la palabra de confianza del catequista relugiado: "miles de inocentes han muertos, que no conoce el pecado todavía, pues ojalá que Dios los ha puesio en su mano las almas de esos hermanos. Muchos los hermanos han dado su vida, han derramado su sangre por sus hermanos. Pues han recibido un bautismo de sangre."

$\mathrm{Y}$ los vivos que no cayeron bajo las balas enemigas, ifueron ellos liberados por Dios, como lo experimentó el sobreviviente? ¿El refugiado tiene la misma experiencia? Básicamente si, aunque éste no acude en la elaboración de su pensamiento a instancias concretas para mostrarlo, sino que sólo habla de una voluntad de Dios constatada por el pueblo. Esta voluntad consiste en que "Dios no quiere que morimos todos." Evidentemente esta afirmación no se apoya sobre una lógica apodictica. Se basa en la experiencia de que los refugiados están vivos y en la intuición (fe) y confianza (esperanza) de que Dios no permitirá por su amor a los pobres el genocidio completo. Las masacres pueden diezmar al pueblo, pero no pueden acabarlo. $Y$ no pueden acabarlo, porque si asi fuera Dios sería derrotado por el mal. Pero Dios es vencedor y la prueba de que lo es es que su hijo, que en si resume a todos los pobres perseguidos, vive. Su hijo Jesucristo fue resucitado.

Ahora bien, esta victoria de Dios, que se manifiesta en el gozo de vivir, es una exigencia continua a seguir luchando: "pues demos gracias a Dios por estar gozando otros días más. Dios no quiere que morimos todos, sino Dios quiere a los que estamos vivos todavía esforzamos la lucha para llegar a la meta en nuestro Señor Jesucristo, y estar bien clara por nuestra vida de hoy, esta lemporada."

\section{Rasgos de Dios}

De todo lo dicho, ¿cómo podemos caracterizar la imagen de Dios de refugiado? Un contraste con ia del sobreviviente de la masacre puede iluminar este punto, si tenemos en cuenta que no son dos imágenes exclusivas, ni contradictorias, aunque debido al momento que cada uno eslá viviendo en una se acentúen algunos aspectos y en la otra otros.

Podriamos decir que la del refugiado es la imagen de un Dios más hombre (Jesucristo) que Dios, de un Dios más hermano que padre, de un Dios más de 
resistencia que de liberación puntual maravillosa, más de esfuerzo que de gratitud, de uı Dios más parcial que universal, más castigador del malvado que perdonador del pecador inocente, más del futuro que del pasado, más dialéclico (perseguido y resucitado) que univoco (el más grande), más de resurrección y de luz que de oscuridad y de prueba de muerte.

Sobre este último punto, queremos indicar que aunque el refugiado mencione la cadena de suirimientos de su pueblo, sin embargo, continuamente invierte su experiencia con la lie en Jesucrisio, sacando luz de la oscuridad. consuclo de la Iristeza. gozo de la paciencia. resistencia de la debilidad. Sul lé, por eso, es fe de vida, aunque cste acosado por las penas y las angustias.

No queremos decil que la te del sobreviviente tenga un Dios de muerle. Nada más contrario a li profundiclatl de su experiencia religiosa del Dios que lo liberó. Pero si que, debido a la cercania de la masacre y a la oscuridad en que se debate por encontrar respuesia a su pregunta torturadora, su Dios es más el del misterio, de la noche oscura y de la muerte espiritual, que el del camino, de la luz y del consuelo íntimo.

\section{Fraternidad y resurrección}

Por fin, para enlazar con la experiencia del refugiado de su identidad como tal, queremos mostrar cómo la hermandad nueva de los refugiados entre si se comprende y siente como una gracia de la resurrección de Cristo. ¿Cómo se entiende esto?

El refugiado escribe a sus familiares lejanos y les dice que esa comunicación es una resurrección. Ellos no sabian si él, su esposa e hijos esıaban vivos. Ellos no sabian si los demás de la aldea habian caído bajo las balas del ejército. La comunicación de la carıa lleva precisamente como una de las finalidades informar sobre quiénes viven y quiénes ya no. Por eso el saludo del catequista es como la resurección del que estaba muerto, pero he aqui que, oh sorpresa. vive. Y esa resurrección es la misma de .lesucristo.

l.a connunicación de la noticia no es un hecho informativo, seco y frio, sino que a la vez es la transmisión de un flujo de emoción, de cariño, de lágrimas, cle consuclo, propio de las visias del resucitado a los suyos: "llegue a todos usıcdes (esta carta) con ıodo aquel cariño de ıni corazón, saludando por ustedes uno de sus hermanos o familiar suyos de nombre $\mathrm{XX}$, que hov he resucirado para poder saludarlc con todo ustedes, pues saben ustedes desde cuando hemos despidido sin poder comunicar nada."

México, 5 de julio de 1985. 